\title{
Rotavirus infection in a tertiary hospital: laboratory diagnosis and impact of immunization on pediatric hospitalization
}

\begin{abstract}
Background and objectives: Rotavirus (RV) is the main etiological agent of diarrhea in childhood; its laboratory diagnosis is crucial to guide the clinical management and prevention of its spread. RV immunization was introduced in Brazilian 6-month-old children in 2006. The present study was aimed to evaluate three methodologies used for human RV detection in stool samples obtained from patients hospitalized due to gastroenteritis in a teaching hospital and report the impact of RV immunization in hospitalization by diarrhea. Methods: 293 stool samples collected in the 2001-2008 period were analyzed by enzyme immunoassay (EIA), latex agglutination (LA) and polyacrylamide gel electrophoresis (PAGE). Results: Rotavirus was detected in $34.8 \%$ of samples by LA assay, $28.3 \%$ of samples by EIA assay and in $25.6 \%$ of samples by PAGE assay. Considering the PAGE method as gold standard, the sensitivity, specificity and accuracy of EIA were $94.6 \%, 94.4 \%$ and $94.5 \%$, and to LA were $82.6 \%, 81.6 \%$ and $81.9 \%$, respectively. Conclusions: These results indicate that antigen detection by EIA is a rapid, sensitive and specific method, and could be used in large-scale applications for screening stool samples suspected of RV infection. This study showed decreased incidence of RV infection in hospitalized children prior to the implementation of the national immunization program against RV.
\end{abstract}

Keywords: rotavirus; diarrhea; immunoenzyme techniques; latex fixation tests; electrophoresis; polyacrylamide gel.

[Braz J Infect Dis 2011;15(3):215-219]@Elsevier Editora Ltda.

\section{INTRODUCTION}

Diarrhea is a leading cause of deaths in children despite the decline in mortality observed over the past few years. ${ }^{1,2}$ Rotavirus (RV) is the most important etiological agent of diarrhea in children under five years old, and accounts for 111 million episodes of gastroenteritis in the world, and for approximately 611,000 deaths annually, mainly in developing countries. ${ }^{2}$ In Brazil, several studies were conducted to demonstrate the importance of RV in children morbidity and mortality. ${ }^{3-10}$

The rotavirus belongs to the Reoviridae family, exhibits icosahedral symmetry, it is not enveloped and was first identified by electron microscopy by Bishop et al. ${ }^{11}$ The viral particle consists of three layers of protein and the viral genome consists of 11 segments of double-stranded RNA (dsRNA), which encode six structural proteins, VP1-4, VP6 and VP7 and six non-structural proteins, NSP1-6. ${ }^{12,13}$ The VP6 protein, located in the inner capsid of the virus contains the antigenic determinants, which allow their classification into seven serogroups of A to G, with group A being the most common agent of childhood diarrhea. ${ }^{2,6,13,14}$ $\mathrm{RV}$ infection can range from mild diarrhea, with limited duration, to a severe case, with fever, vomiting and dehydration. ${ }^{15-17}$

Laboratory diagnosis of rotavirus infection is usually performed by antigen detection, using enzyme immunoassay ${ }^{15}$ or latex agglutination (LA) techniques, which have a sensitivity and specificity above $90 \%$. Molecular techniques such as polyacrylamide gel electrophoresis (PAGE) and reverse transcription-polymerase chain reaction (RT-PCR) are used to determine the RNA migration patterns and virus genotyping, respectively. ${ }^{18-21}$

In 2006, the RV vaccine was introduced by the Brazilian National Immunization Program for children younger than six months. Since then, the impact of this immunization has been analyzed by monitoring the decrease of children hospitalization due to gastroenteritis and by laboratorial surveillance based on viral antigen tests results. ${ }^{22}$ The virology
Authors

Luciane Aparecida

Pereira $^{1}$

Sonia Mara Raboni ${ }^{2}$

Meri B Nogueira ${ }^{3}$

Luine R Vidal ${ }^{4}$

Sergio Monteiro de

Almeida $^{5}$

Maria C Debur ${ }^{6}$

Cristina Cruz ${ }^{7}$

${ }^{1} \mathrm{MSc}$; Biologist in the

Laboratory of Virology,

Universidade Federal do

Paraná, Brazil

${ }^{2} \mathrm{PhD}$; Associated Professor

Infectious Diseases

Departament, Universidade

Federal do Paraná, Brazil

${ }^{3} \mathrm{PhD}$; Biochemistry

Laboratory of Virology,

Universidade Federal do

Paraná, Brazil

${ }^{4} \mathrm{MSc}$; Biochemistry

Laboratory of Virology,

Universidade Federal do

Paraná, Brazil

${ }^{5} \mathrm{PhD}$; Neurologist

Laboratory of Virology,

Universidade Federal do

Paraná, Brazil

${ }^{6} \mathrm{MSc}$; Biochemistry Central

Laboratory of Public

Health, Secretaria Estadual

de Saúde do Paraná, Brazil

${ }^{7} \mathrm{PhD}$; Pediatric

Infectologist Associated

Professor, Universidade

Federal do Paraná, Brazil

Submitted on: 11/25/2010 Approved on: 02/18/2011

Correspondence to: Sonia Mara Raboni Laboratório de Virologia, Hospital de Clínicas, UFPR

Rua Padre Camargo, 280,

$2^{\text {nd }}$ floor, Room 202

Alto da XV, Curitiba,

Paraná, Brazil

82060-240

Phone: 5541 3360-7974

Fax: 5541 3360-1811

sraboni@ufpr.br // sonia.

raboni@pq.cnpq.br

We declare no conflict of interest. 
laboratory of Hospital de Clínicas - Universidade Federal do Paraná (HC-UFPR), a teaching hospital, has detected this virus in children hospitalized due to gastroenteritis. Screening by antigen detection using EIA or LA methods was carried out, followed by PAGE techniques to perform viral profile analysis. Positive samples for the detection of viral antigens are notified and sent to reference laboratories for genetic characterization. The results of these laboratory screening tests and the impact of the immunization on the incidence of RV infection in children admitted to the Hospital de Clínicas - UFPR are presented in this study.

\section{MATERIALS AND METHODS}

Stool samples from patients with acute gastroenteritis admitted to the HC-UFPR from April 2001 to December 2008 were analyzed using the LA and EIA for antigen detection, and PAGE for RNA detection methods.

The stool samples were collected in plastic vials without preservatives and sent to the virology laboratory immediately after collection. The samples were then processed or stored at $-20^{\circ} \mathrm{C}$ for as long as 24 hours before processing.

EIA was performed using Rotascreen II kit ${ }^{\oplus}$ (Rotascreen II-Microgen-Bioproducts- Camberley, U.K.) or EIARA kit (Immunoassay for rotavirus and adenovirus-Biomanguinhos, RJ, Brazil). Latex agglutination was carried out using Virotect kit ${ }^{\circledR}$ (Omega Diagnostics, Scotland, United Kingdom) or Rotascreen ${ }^{\bullet}$ Kit (Rotascreen-Microgen-Bioproducts, Camberley, U.K). Both methods were performed according to the manufacturer's instructions. All tests kits cover all the requirements of the Brazilian Sanitary Surveillance Agency (ANVISA) for use in laboratory diagnosis. Furthermore, they were validated by the local virology laboratory, where the analysis of a previously characterized group of samples was carried out.

PAGE was standardized using the method previously reported by Boom et al. ${ }^{23}$ with some modifications for the extraction of viral RNA and separation of genomic segments. ${ }^{24}$ The RNA was loaded onto a polyacrylamide discontinuous gel (7.5\% - separator and 3.5\% - concentrator) for 2 hours at $100 \mathrm{~V}$. The gel wa s stained with silver nitrate using the method of Herring et al. ${ }^{25}$ RNA extracted from simian RV (SA11) was used as positive control on PAGE analysis.

\section{Statistical analysis}

Descriptive analysis was performed for all variables. Data were stored and analyzed using JMP Software Version 5.2.1. Sensitivity, specificity, accuracy, likelihood ratios (LRs), positive and negative predictive values were calculated using binomial exact methods. According to these calculations, a specimen was considered to contain the rotavirus when it was positive by PAGE (gold standard). Agreement between the assays was evaluated using Kappa coefficient.
Kappa values above 0.75 indicate strong agreement; values between 0.40 and 0.75 represent fair to good agreement and values below 0.40 reflect poor agreement. Correlation between EIA, LA and PAGE was analyzed using the Spearman correlation coefficient. The differences between groups were analyzed using Chi-square test or Fisher's exact test, as appropriate. All tests were over two-tails. A p-value $<0.05$ was considered statistically significant.

\section{Ethics}

The procedures involving the use of the bank of clinical samples from the laboratory of virology for the detection of $\mathrm{RV}$ in human stool samples had the approval of the Committee on the Ethics of Research on Human Beings of the HC-UFPR, under registration number 4441.023/2002-04.

\section{RESULTS}

A total of 293 fecal samples collected from 286 children with acute gastroenteritis were analyzed. The rotavirus antigen was detected in $34.8 \%(102 / 293)$ of the samples by LA, $28.3 \%(83 / 293)$ by EIA and in $25.5 \%$ (75/293) by PAGE.

Figure 1 shows the distribution of positive samples by the different diagnostic tests and the total amount of samples collected each year. Overall, there was a good correlation between the tests, though not for all the years of the study. Significant differences between the results were observed in 2007 when all samples were positive only by latex agglutination, characterizing false positive results. A decline in the number of patients positive for rotavirus has been observed since 2004, two years before the vaccine introduction.

Compared to PAGE, EIA presented $94.6 \%, 94.4 \%$ and $94.5 \%$ of sensitivity, specificity and accuracy, respectively. The positive predictive value was $85.5 \%$ and the negative predictive value was $98 \%$. The sensitivity, specificity and accuracy of the LA test were respectively $82.6 \%, 81.6 \%$ and $81.9 \%$. The positive predictive value was $60.7 \%$ and the negative predictive value was $93.1 \%$. Considering all the results obtained, the agreement beyond chance between the tests (Kappa measures) was 0.86 and 0.57 for

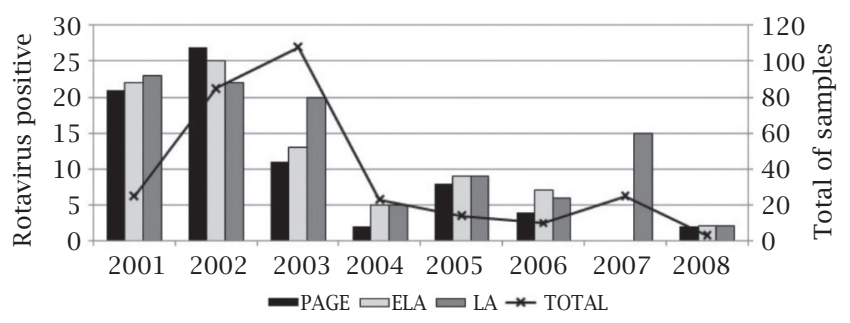

Figure 1: Rotavirus positive results and number of samples studied, 2001-2008.

PAGE, polyacrylamide gel electrophoresis; EIA, enzyme immunoassay; LA, latex agglutination. 


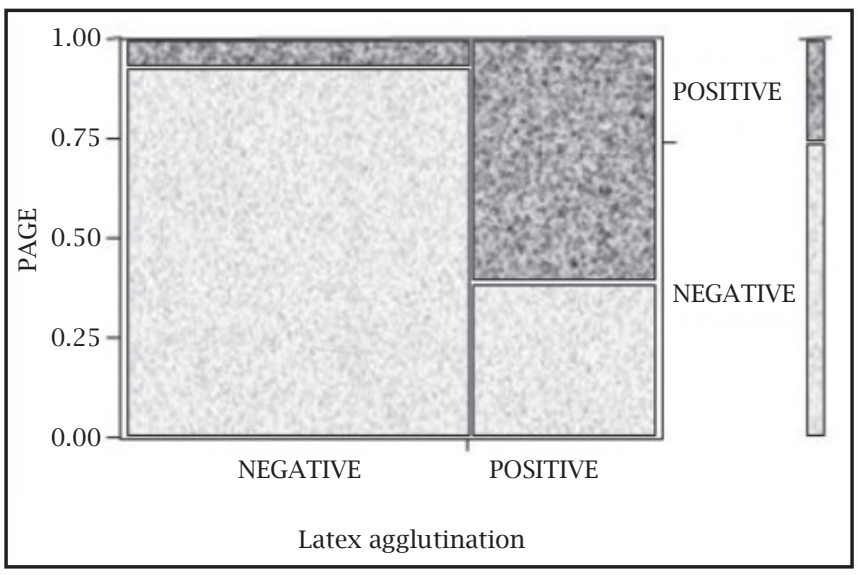

Kappa measures: 0,57 \pm 0.05

Likelihood rate (+): 4.3

Likelihood rate (-): 0.2

Operational characteristics

Sensitivitty $=82.6 \%$

Specifcity $=81.6 \%$

Accuracy $=81.9 \%$

Positive predictive value $=60.7 \%$

Negative predictive value $=93.1 \%$

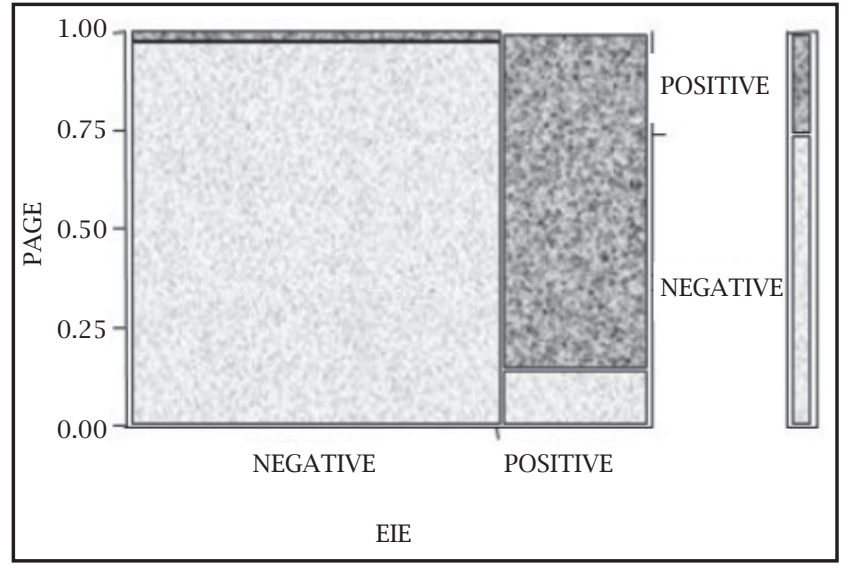

Kappa measures: 0,86 \pm 0.03

Likelihood rate (+): 15.6

Likelihood rate (-): 0.06

Operational characteristics

Sensitivitty $=94.6 \%$

Specifcity $=94.4 \%$

Accuracy $=94.5 \%$

Positive predictive value $=85.5 \%$

Negative predictive value $=98.0 \%$

Figure 2: Rotavirus diagnosis. Contingency table and operational characteristics of antigen detection tests.

PAGE, polyacrylamide gel electrophoresis; EIA, enzyme immunoassay.

EIA and LA, respectively. The likelihood ratio values of EIA (LR+ and LR-) demonstrated that, unlike LA, test results were essential to help confirm diagnosis. There was no significant difference between PAGE and EIA ( $p=0.51)$, in contrast to the comparison between PAGE and LA $(\mathrm{p}=0.018)$.

Figure 2 shows the contingency table obtained by comparison of the results of EIA and LA with PAGE results, and the summary of the operational characteristics of the tests of rotavirus antigen detection.

\section{DISCUSSION}

Several decades after the rotavirus' description, many studies have been carried out to compare detection techniques. ${ }^{19,26-31}$ Currently, several commercial tests are available from those based on less laborious techniques that enable a quick diagnosis, e.g. antigen detection methods, to more complex tests such as the polymerase chain reaction. ${ }^{32-34}$

In this study, we evaluated different antigen detection tests for establishing the diagnosis of rotavirus infection in stool samples from children with gastroenteritis. The prevalence of RV-associated diarrhea of $25.6 \%$ (75/293) was similar to that reported in Brazil ${ }^{35,36}$ and in other countries. ${ }^{37,38}$ PAGE is an important tool to understand the epidemiology of RV and it was chosen as the gold standard test due to its specificity and practicability and also, because it de- tects non-A RV. ${ }^{39-41}$ However, its use as screening test is not recommended due to the need for technical training for its implementation and longer time of execution. ${ }^{42}$ Some positive results to antigen detection by EIA and LA were found, though with negative results by PAGE. It is important to mention that the antigen detection tests using PAGE were carried out at different moments, and the samples were frozen at $-70^{\circ} \mathrm{C}$ for different periods, which may have affected PAGE results.

There was no significant difference between the EIA and PAGE methods. The positive and negative likelihood ratio showed that EIA positive and negative results can be used to confirm diagnosis of rotavirus infection. These results indicate that EIA assay is as sensitive and specific as the PAGE method, and could be applied on a large scale from the screening of stool suspected of rotavirus diarrhea, having a good correlation with the disease. ${ }^{21,34,43,44}$

Agreement beyond chance the tests between LA and PAGE showed regular/good agreement, demonstrating low sensitivity for latex agglutination test, as shown in other studies. ${ }^{20,45-47}$ Regarding specificity, some authors report that, unlike our findings, they have found values above $90 \%$, where the specificity obtained in this study was $81.9 \%{ }^{42,48}$ In general, the results obtained by PAGE and EIA had strong agreement, unlike the findings for PAGE and LA. Recent reports show that the performance of commercially available latex agglutination tests compares favorably to 
virus isolation and ELISA. ${ }^{49}$ Nevertheless, in this study, the variability observed in LA results for some years has strongly jeopardized its reliability as a screening test. Thus, it has not been possible to predict the occurrence (or nonoccurrence) of the disease based on LA results. Although this technique may be useful in certain situations, such as outbreaks of the disease, or in locations with lack of resources for RV detection, because it is fast, practical and has low cost. ${ }^{31,50}$

A different distribution of positive samples was observed using this method in different years, with a progressive decline in the number of samples investigated since 2004. A study to assess the impact of vaccination against rotavirus has been previously conducted by our institution. The number of outpatient appointments and hospital admissions for gastroenteritis before and after the implementation of the vaccine (2005 and 2007) was assessed. That study showed a reduction of $54.2 \%$ and $39.4 \%$ of medical appointments for children less than 12 months old and 12 to 60 months old respectively. Furthermore, there was also a reduction of $43.9 \%$ and $33.3 \%$ of hospital admissions due to gastroenteritis in children less than 12 months old and 12 to 60 months old, respectively, considering vaccination coverage around $80 \%$ in the referred period. ${ }^{51}$

The decline in the number of positive cases observed in this study, before vaccine implementation, can be explained by the improvement of sanitation conditions (access of the poorest populations of the region to safe sanitation) and also by the success of public health policies based on the availability of primary care at health units and by the policy of the teaching hospital of referring severe cases to tertiary care.

Despite the fact that the vaccination program is being implemented on a continuous basis and its initial impact on the reduction of cases of rotavirus infection, we found that hospital admissions for severe cases of the infection persist in the tertiary hospital. This can be explained by the occurrence of the disease in patients with risk factors who did not respond to vaccine or were not vaccinated. Therefore, it is essential to proceed with laboratory diagnosis of this disease, as well as to monitor viral genetic variability, which could influence the response to immunization.

$\mathrm{RV}$ vaccines have been introduced in Brazilian Immunization Calendar and the surveillance has been made by laboratory diagnosis using antigen detection methods. It is important to assess the performance of these methods in order to know how these can influence the data obtained and to try to maintain a homogenous guidelines for laboratory tests in all public laboratories. Concerning the methodologies employed to diagnose RV, the results of this study stress the need for constant evaluations of the performance of RV detection tests due to the great availability of kits in the market.

\section{CONCLUSION}

A few laboratories in Brazil perform tests to diagnose RV infection, and there is not a standardization of what methods should be used. These results indicate that antigen detection by LA has higher sensitivity, but lower specificity than EIA, which is a rapid, sensitive and specific method, and could be used in large-scale for screening of stool samples suspected of RV infection. EIA would provide the most appropriate information to monitoring RV infection, and consequently yield the clearest baseline information to assess immunization response.

\section{REFERENCES}

1. Morillo SG, Luchs A, Cilli A, Costa FF, Carmona RC, Timenetsky MC. Characterization of rotavirus strains from day care centers: pre- and post-rotavirus vaccine era. J Pediatr. (Rio J) 2010; 86(2):155-8.

2. Parashar UD, Gibson CJ, Bresse JS, Glass RI. Rotavirus and severe childhood diarrhea. Emerg Infect Dis. 2006; 12(2):304-6.

3. Kapikian A, Hoshino Y, Chanock R. Rotaviruses. In: Knipe D, Howley P, editors. Fields Virology. Philadelphia: Lippincott Williams \& Wilkins. 2001

4. Linhares AC. Rotavirus Infection in Brazil: Epidemiology, Immunity, and Potential Vaccination. Braz J Infect Dis. 1997; 1(6):284-93.

5. Mascarenhas JD, Gusmao RH, Barardi CR et al. Characterization of rotavirus $\mathrm{P}$ genotypes circulating among paediatric inpatients in northern Brazil. Rev Inst Med Trop Sao Paulo 1999. 41(3):165-70.

6. Meneghetti A, Bolognini A, Lauretti F, Linhares R, Santos N, Nozawa C. Incidence of group A rotavirus in urban and rural areas of the city of Londrina - Brazil, from 1995 to 1997. Braz Arch Biol Technol. 2001; 44(3):257-61.

7. Richardson V, Hernandez-Pichardo J, Quintanar-Solares M et al. Effect of rotavirus vaccination on death from childhood diarrhea in Mexico. N Engl J Med. 2010; 362(4):299-305.

8. Sartori AM, Valentim J, de Soarez PC, Novaes HM. Rotavirus morbidity and mortality in children in Brazil. Rev Panam Salud Publica 2008; 23(2):92-100.

9. Souza MB, Racz ML, Leite JP, Soares CM, Martins RM, Munford V, Cardoso DD. Molecular and serological characterization of group a rotavirus isolates obtained from hospitalized children in Goiania, Brazil, 1998-2000. Eur J Clin Microbiol Infect Dis. 2003. 22(7):441-3.

10. Timenetsky MC, Santos N, Gouvea V. Survey of rotavirus $\mathrm{G}$ and $\mathrm{P}$ types associated with human gastroenteritis in Sao Paulo, Brazil, from 1986 to 1992. J Clin Microbiol. 1994; 32(10):2622-4.

11. Bishop RF, Davidson GP, Holmes IH, Ruck BJ. Virus particles in epithelial cells of duodenal mucosa from children with acute non-bacterial gastroenteritis. Lancet 1993; 2(7841):1281-3.

12. Desselberger U. Molecular epidemiology of rotaviruses. In: Farthing M, editor. Viruses and the gut. London: Swan. 1989.

13. Estes M. Rotaviruses and their replication. In: Knipe D, Howlwy P, editors. Fields Virology. 4 ed. Philadelphia: Lippincott Willians \& Wilkins. 2001.

14. Estes MK, Cohen J. Rotavirus gene structure and function. Microbiol Rev 1989; 53(4):410-9. 
15. Cauás R, Falbo A, Correia J, Oliveira K, Montenegro F. Diarréia por rotavírus em crianças desnutridas hospitalizadas no Instituto Materno Infantil Prof. Fernando Figueira, IMIP. Rev Bras Saude Mater Infant. 2006; 6:s77-s83.

16. Costa P, Grisi S, Cardoso D, Fiaccadori F, Souza M, Santos R. Clinical and epidemiological trends in rotavirus A infections. Pediatria (São Paulo) 2004; 26(3):151-8.

17. Nunes A, Mello L, Parrode R, Bittar J. Prevalence of rotavirus in feces of children with acute diarrhea: clinical signs and associated symptoms. Revista da AMRIGS 2010; 54(2):147-51.

18. Beards GM, Campbell AD, Cottrell NR et al. Enzyme-linked immunosorbent assays based on polyclonal and monoclonal antibodies for rotavirus detection. J Clin Microbiol. 1984.; 19(2):248-54.

19. Buesa J, Colomina J, Raga J, Villanueva A, Prat J. Evaluation of reverse transcription and polymerase chain reaction (RT/PCR) for the detection of rotaviruses: applications of the assay. Res Virol. 1996; 147(6):353-61.

20. Ferreira T, Becho M, Bernardo A et al. Performance of a latex agglutination test in the diagnosis of acute gastroenteritis by rotavirus. Braz J Microbiol. 2006; 37(4):587-9.

21. Kasempimolporn S, Louisirirotchanakul S, Sinarachatanant P, Wasi C. Polyacrylamide gel electrophoresis and silver staining for detection of rotavirus in stools from diarrheic patients in Thailand. J Clin Microbiol. 1988; 26(1):158-60.

22. Ruiz-Palacios GM, Perez-Schael I, Velazquez FR et al. Safety and efficacy of an attenuated vaccine against severe rotavirus gastroenteritis. N Engl J Med. 2006; 354(1):11-22.

23. Boom R, Sol CJ, Salimans MM, Jansen CL, Wertheim-van Dillen PM, van der Noordaa J. Rapid and simple method for purification of nucleic acids. J Clin Microbiol. 1990; 28(3):495-503.

24. Laemmli UK. Cleavage of structural proteins during the assembly of the head of bacteriophage T4. Nature 1970; 227(5259):680-5.

25. Herring AJ, Inglis NF, Ojeh CK, Snodgrass DR, Menzies JD. Rapid diagnosis of rotavirus infection by direct detection of viral nucleic acid in silver-stained polyacrylamide gels. J Clin Microbiol. 1982; 16(3):473-7.

26. Bellamy K, Gardner PS, Hambling MH, Rice S, Bradburne AF. Enzyme-linked immunosorbent assay for the detection of human rotavirus in stools. J Virol Methods 1983; 7(2):65-72.

27. Berthiaume L, Alain R, McLaughlin B, Payment P, Trepanier P. Rapid detection of human viruses in faeces by a simple and routine immune electron microscopy technique. J Gen Virol. 1981; 55(Pt 1):223-7.

28. Grauballe PC, Jarzabek Z. Comparison of indirect double antibody and double antibody sandwich ELISA techniques with latex agglutination test for the diagnosis of human rotavirus infection. Acta Virol. 1984; 28(1):59-63.

29. Middleton PJ, Holdaway MD, Petric M, Szymanski MT, Tam JS. Solid-phase radioimmunoassay for the detection of rotavirus. Infect Immun. 1977; 16(2):439-44.

30. Nakagomi O, Nakagomi A, Suto $\mathrm{T}$ et al. Detection of human rotavirus by reversed passive hemagglutination (RPHA) using antibody against a cultivable human rotavirus as compared with electron microscopy (EM) and enzyme-linked immunosorbent assay (ELISA). Microbiol Immunol. 1982; 26(8):747-51.

31. Raboni SM, Nogueira MB, Hakim VM, Torrecilha VT, Lerner $\mathrm{H}$, Tsuchiya LR. Comparison of latex agglutination with enzyme immunoassay for detection of rotavirus in fecal specimens. Am J Clin Pathol. 2002; 117(3):392-4.

32. Carraro E, Perosa A, Siqueira I, Pasternak J, Martino M. Four kits evaluation for rotavirus rapid antigen detection in stool samples. Rev Bras Anal Clin. 2008; 40(4):309-11.

33. Masendycz PJ, Palombo EA, Gorrell RJ, Bishop RF. Comparison of enzyme immunoassay, $\mathrm{PCR}$, and type-specific cDNA probe techniques for identification of group A rotavirus gene 4 types (P types). J Clin Microbiol. 1997; 35(12):3104-8.

34. Momenzadeh A, Modarres S, Faraji A et al. Comparision of enzyme immunoassay, immunochromatography, and RNA-polyacrylamide gel electrophoresis for diagnosis of rotavirus infection in children with acute gastroenteritis. Iran J Med Sci. 2008; 33(3):173-6.

35. Linhares AC. Rotavirus infection in Brazil: epidemiology and challenges for its control. Cad Saude Publica 2000; 16(3):629-46.

36. Munford V, Souza E, Caruzo T, Martinez M, Rácz M. Serological and molecular diversity of human rotavirus in São Paulo, Brazil. Braz J Microbiol. 2007; 38(3):459-66.

37. Bresee J, Fang ZY, Wang B et al. First report from the Asian Rotavirus Surveillance Network. Emerg Infect Dis 2004; 10(6):988-95.

38. Parashar UD, Hummelman EG, Bresee JS, Miller MA, Glass RI. Global illness and deaths caused by rotavirus disease in children. Emerg Infect Dis. 2003; 9(5):565-72.

39. Altindis M, Yavru S, Simsek A, Ozkul A, Ceri A, Koc H. Rotavirus infection in children with acute diarrhea as detected by latex agglutination, ELISA and polyacrylamide gel electrophoresis. Indian Pediatr. 2004; 41(6):590-4.

40. Gomez JA, Bercovich JA, Grinstein S. Comparison of enzyme immunoassay, counterimmunoelectrophoresis and polyacrylamide gel electrophoresis for the diagnosis of rotaviruses. Rev Argent Microbiol. 1985; 17(2):111-4.

41. Ibrahim OS, Sunderland D, Hart CA. Comparison of four methods for detection of rotavirus in faeces. Trop Doct. 1990; 20(1):30-2.

42. Chakravarti A, Kumar S, Mittal SK, Broor S. Comparison of latex agglutination and polyacrylamide gel electrophoresis with enzyme linked immunosorbent assay for detecting human rotavirus in stool specimens. Indian Pediatr. 1991; 28(5):507-10.

43. Brandt CD, Arndt CW, Evans GL et al. Evaluation of a latex test for rotavirus detection. J Clin Microbiol. 1987; 25(9):1800-2.

44. Cornaglia E, Barrandeguy M, Fijtman N, Schudel A. Enzyme linked immunosorbent, immunofluorescence test and electrophoretic analysis of rotaviral RNA in the diagnosis and characterization of the bovine rotavirus. Rev Latinoam Microbiol. 1989; 31(1):59-62.

45. Carducci A, Vannucchi R, Guidi M, Reali D, Ruschi MA. Human rotavirus detection in stool specimens using enzyme-linked immunosorbent assays and latex agglutination test. Boll Ist Sieroter Milan 1988; 67(3):241-4.

46. Dennehy PH, Gauntlett DR, Tente WE. Comparison of nine commercial immunoassays for the detection of rotavirus in fecal specimens. J Clin Microbiol. 1988; 26(9):1630-4.

47. Thomas EE, Puterman ML, Kawano E, Curran M. Evaluation of seven immunoassays for detection of rotavirus in pediatric stool samples. J Clin Microbiol. 1988; 26(6):1189-93.

48. Pirkooh A, Shahrabadi M. Development of a latex agglutination method for diagnosis of rotavirus infections. Iran J Med Sci. 2007; 32(2):100-4.

49. Maes RK, Grooms DL, Wise AG et al. Evaluation of a human group a rotavirus assay for on-site detection of bovine rotavirus. J Clin Microbiol. 2003; 41(1):290-4.

50. Jensen A. Evaluation of two commercial kits for rapid detection of human rotavirus in feces: Rotalex, a latex agglutination test and Rotavirus ELISA Kit. Acta Pathol Microbiol Immunol Scand B 1985; 93(2):159-60.

51. Rodrigues C, Zattar J, Rossoni A, Stroparo E, Roque D, Romagnoli L. Impact of vaccination against rotavirus in outpatients visitis and hospitalization due to gastroenteritis in a university hospital in Brazil. 6th Annual Meeting of the World Society for pediatric Infectious Diseases. Buenos Aires 2009. 